University of Nebraska - Lincoln

DigitalCommons@University of Nebraska - Lincoln

Impact of temperature and relative humidity on life history parameters of adult Sitotroga cerealella (Lepidoptera: Gelechiidae)

James E. Throne

USDA-ARS, Manhattan, KS, james.throne@ars.usda.gov

David K. Weaver

Montana State University, weaver@montana.edu

Follow this and additional works at: https://digitalcommons.unl.edu/usdaarsfacpub

Throne, James E. and Weaver, David K., "Impact of temperature and relative humidity on life history parameters of adult Sitotroga cerealella (Lepidoptera: Gelechiidae)" (2013). Publications from USDA-ARS / UNL Faculty. 2059.

https://digitalcommons.unl.edu/usdaarsfacpub/2059

This Article is brought to you for free and open access by the U.S. Department of Agriculture: Agricultural Research Service, Lincoln, Nebraska at DigitalCommons@University of Nebraska - Lincoln. It has been accepted for inclusion in Publications from USDA-ARS / UNL Faculty by an authorized administrator of DigitalCommons@University of Nebraska - Lincoln. 


\title{
Impact of temperature and relative humidity on life history parameters of adult Sitotroga cerealella (Lepidoptera: Gelechiidae)
}

\author{
James E. Throne ${ }^{\mathrm{a}, *}$, David K. Weaver ${ }^{\mathrm{b}}$ \\ ${ }^{a}$ USDA, Agricultural Research Service, Center for Grain and Animal Health Research, 1515 College Avenue, Manhattan, KS 66502-2736, USA \\ ${ }^{\mathrm{b}}$ Department of Land Resources and Environmental Sciences, Montana State University, P.O. Box 173120, Bozeman, MT 59717-3120, USA
}

\section{A R T I C L E I N F O}

\section{Article history:}

Accepted 17 October 2013

\section{Keywords:}

Egg survivorship

Fecundity

Longevity

Stored-product insect

\begin{abstract}
A B S T R A C T
The Angoumois grain moth, Sitotroga cerealella (Olivier) (Lepidoptera: Gelechiidae), is a pest of stored corn, Zea mays L., and other grains throughout the world. Sitotroga cerealella are routinely exposed to temperatures below $20^{\circ} \mathrm{C}$ in regions of the U.S. where corn is grown, yet there are no data describing adult life history parameters below $20^{\circ} \mathrm{C}$. We determined longevity, fecundity, and survivorship of eggs at a range of temperatures that represent environmental conditions to which S. cerealella are exposed in corn stored in the U.S. Longest male longevity was $31 \mathrm{~d}$ at $10^{\circ} \mathrm{C}$, and shortest male longevity was $4 \mathrm{~d}$ at 35 and $40{ }^{\circ} \mathrm{C}$. Longest female longevity was $29 \mathrm{~d}$ at $15^{\circ} \mathrm{C}$, and shortest female longevity was 5 days at 35 and $40{ }^{\circ} \mathrm{C}$. Duration of the preoviposition period was as long as $16 \mathrm{~d}$ at $10^{\circ} \mathrm{C}$ and as short as $1 \mathrm{~d}$ at 30 $-40{ }^{\circ} \mathrm{C}$. All females laid eggs at $20-30{ }^{\circ} \mathrm{C}, 50-94 \%$ of females laid eggs at $15{ }^{\circ} \mathrm{C}$, and $17-61 \%$ of females laid eggs at 10,35 , or $40^{\circ} \mathrm{C}$. Females laid the most eggs, nearly 100 , at 20 and $25^{\circ} \mathrm{C}$ and $75 \%$ r.h., while 6 or fewer eggs were laid at 10,35 , or $40^{\circ} \mathrm{C}$. Between 68 and $98 \%$ of eggs hatched at $20-30^{\circ} \mathrm{C}$, while $20 \%$ or fewer eggs hatched at $35{ }^{\circ} \mathrm{C}$ and no eggs hatched at $40{ }^{\circ} \mathrm{C}$. An average of less than one egg was laid at $10{ }^{\circ} \mathrm{C}$, but $58-100 \%$ of eggs hatched at $10^{\circ} \mathrm{C}$. Our results emphasize the importance of including data on population growth of stored-grain insect pests at low temperatures in computer models for simulating insect population growth in grain.
\end{abstract}

Published by Elsevier Ltd.

\section{Introduction}

The Angoumois grain moth, Sitotroga cerealella (Olivier) (Lepidoptera: Gelechiidae), is a major pest of stored corn, Zea mays L., and other grains throughout the world. Damage to grain is generally limited to the top $23 \mathrm{~cm}$ of grain in bulk storage because the moths can't penetrate further into the grain mass (Shahjahan, 1975). Despite this, S. cerealella can cause considerable damage because, after oviposition on the outside of grain kernels, a newly hatched larva penetrates a kernel and completes its development inside the kernel, consuming much of the kernel and depositing frass.

Effects of temperature and relative humidity on development of immature S. cerealella have been reported in a number of studies for different geographical populations developing on different commodities, including for a U.S. strain developing on stored corn

\footnotetext{
* Corresponding author. Present address: USDA, Agricultural Research Service, San Joaquin Valley Agricultural Sciences Center, 9611 South Riverbend Avenue, Parlier, CA 93648, USA. Tel.: +1 559596 2702; fax: +1 5595962951.

E-mail addresses: james.throne@ars.usda.gov (J.E. Throne), weaver@montana. edu (D.K. Weaver).
}

(Perez-Mendoza et al., 2004). Various studies have also reported on effects of temperature and relative humidity on longevity and fecundity of adults from different geographic regions and on different crops. Grewal and Atwal (1969) reported female longevity and fecundity at $20-40{ }^{\circ} \mathrm{C}$ and $40-80 \%$ r.h. on corn. Boldt (1974) reported longevity of females from 20 to $40{ }^{\circ} \mathrm{C}$ and $80 \%$ r.h. on wheat. Shazali and Smith (1985) reported on longevity of both sexes combined and fecundity on sorghum at $25-35^{\circ} \mathrm{C}$ and $60-$ $80 \%$ r.h. Hansen et al. (2004) reported on longevity and fecundity of females of a Nigerian strain developing on corn at $20-35^{\circ} \mathrm{C}$ and 44 and $80 \%$ r.h.

Despite the numerous studies on adult life history parameters of S. cerealella on various crops, none include the full range of temperatures to which $S$. cerealella are exposed in grain stored in the U.S. Arbogast and Throne (1997) found S. cerealella in corn stored in South Carolina throughout the storage season, including during the winter. Although South Carolina is in the southern U.S., they reported temperatures in the stored corn as low as $5{ }^{\circ} \mathrm{C}$ when aeration was used to cool the grain. In fact, they reported that $55 \%$ of the hourly temperatures in two of the bins in their study, and $85 \%$ of temperatures recorded in the third bin, were $20^{\circ} \mathrm{C}$ or less during a storage season. Thus, $S$. cerealella are routinely exposed to temperatures below $20{ }^{\circ} \mathrm{C}$ even in a moderate climate such as that in 
the southern U.S. Weaver and Throne (1994) showed that computer models that simulated $S$. cerealella population growth without including data for when temperatures were below $20{ }^{\circ} \mathrm{C}$ greatly underestimated population growth.

The objective of the current study was to determine longevity of both sexes and fecundity at a broader range of temperatures than investigated in past studies to represent environmental conditions to which $S$. cerealella are exposed in corn stored in the U.S. In addition, we determined fertility and survivorship of eggs produced in the study. These data are essential for developing simulation models that can be used to aid in making pest management decisions.

\section{Materials and methods}

Tests were conducted in two consecutive years, and each year used a different colony of $S$. cerealella. Composite founding populations were collected from farm-stored corn in Blackville and Bamberg, SC, for each year. Stock cultures were reared at $25^{\circ} \mathrm{C}$ and $65 \%$ r.h. on 'Pioneer 3320 ' corn. $\mathrm{F}_{3}$ to $\mathrm{F}_{5}$ progeny were used for three temporal replicates each year.

The tests were conducted at seven temperatures (every $5^{\circ}$ from 10 to $40{ }^{\circ} \mathrm{C}$ ) in environmental chambers which were maintained with light regimes of $16 \mathrm{~L}: 8 \mathrm{D}$. Within each temperature chamber, four relative humidities were maintained separately in four plastic boxes by using saturated salt solutions placed beneath a false floor (potassium carbonate, 40-47\% r.h.; sodium bromide, 53-63\% r.h.; sodium chloride, $75-76.5 \%$ r.h.; and potassium chloride, $82-88 \%$ r.h.; Greenspan, 1977). Equilibrium moisture contents of corn stored over these salt solutions at each temperature are reported in Wicklow et al. (1998).

Three pairs (one male and one female) of adults ( $\leq 24$-h old) were placed one pair per 1/2-pint glass jar $(0.24 \mathrm{~L})$ at each temperature/r.h. combination in each replicate. Accordion-folded black construction paper was the oviposition substrate (Peters, 1971), and these were changed daily. If the male in a jar died before the female, which is what usually occurred, then a new male from the stock culture was placed in the jar. The oviposition papers were held at the oviposition temperature and r.h., and inspected to determine hatch and fertility. Hatched eggs were empty, clear, and crystalline. Unhatched fertile eggs were reddish, and they either retained their original shape or were partly deflated. Infertile eggs were whitish or yellowish, and they generally were at least partially collapsed. We determined time to first oviposition, longevity of males and females, number of eggs laid per female, and percentage egg hatch at each temperature/r.h. combination.

Data were analyzed using the General Linear Models procedure in SAS (SAS Institute, 2008). We used the salt solution over which oviposition papers were equilibrated as an independent variable in the analysis because relative humidities obtained using salt solutions and equilibrium moisture contents vary with temperature. We fit equations to data that would be useful for developing simulation models using TableCurve $2 \mathrm{D}^{\circledR}$ or $3 \mathrm{D}^{\circledR}$ (SYSTAT Software Inc., 2002a, 2002b). When salt solution was included in the equation, we used the measured equilibrium moisture content of corn from Wicklow et al. (1998) because moisture content is usually measured in stored-grain rather than relative humidity. Moisture content can be converted to relative humidity using the equation in Throne (1994). We could not test for lack-of-fit of equations (Draper and Smith, 1981) when equilibrium moisture contents were included as an independent variable in the equation because equilibrium moisture contents vary with temperature so there were not multiple equilibrium moisture contents at each temperature. Equations were chosen for simplicity and because they appeared biologically plausible for the data, but they were not chosen with the intent that they would be extrapolated beyond the environmental conditions tested in this study. So, if used in simulation models, they should be bounded to environmental conditions tested here or their behavior outside the range of our tested environmental conditions should be examined.

\section{Results}

\subsection{Longevity}

Both male and female longevity varied with temperature and salt solution (Tables 1 and 2), and we fit response surfaces to these data (Table 3). Longevity generally decreased as temperature increased within the level of humidity associated with each salt solution and generally increased with increasing relative humidity within a temperature. Males lived as long as 31 days at $10^{\circ} \mathrm{C}$ and as few as four days at 35 and $40{ }^{\circ} \mathrm{C}$, while females lived as long as 29 days at $15^{\circ} \mathrm{C}$ and as few as five days at 35 and $40{ }^{\circ} \mathrm{C}$.

\subsection{Preoviposition, oviposition, and postoviposition periods}

All females laid eggs at $20-30{ }^{\circ} \mathrm{C}$, and $50-94 \%$ of females laid eggs at $15^{\circ} \mathrm{C}$ (Table 4 ). Only $17-39 \%$ of females laid eggs at 10,35 , or $40{ }^{\circ} \mathrm{C}$, except for $61 \%$ of females laying eggs at $35^{\circ} \mathrm{C}$ over $\mathrm{NaCl}$. Duration of the preoviposition, oviposition, and postoviposition periods generally decreased as temperature increased (Tables 5-7). Fewer females laid eggs at temperatures $\geq 35^{\circ} \mathrm{C}$, and there was greater variability in patterns of duration of the preoviposition and postoviposition periods at these temperatures. The effect of salt solution on duration of the preoviposition and oviposition periods was not significant, but there was interaction between temperature and salt solution. However, it was difficult to discern any pattern in effects of salt solution on durations of the preoviposition or oviposition periods as they changed with temperature, so we fit equations to the data for preoviposition and oviposition periods that included only temperature as an independent variable (Table 3). The effect of salt solution on duration of the postoviposition period was significant, but there was no interaction between temperature and salt solution. Duration of the postoviposition period generally increased as the relative humidity corresponding to the salt solutions increased. Duration of the preoviposition period was as long as 16 days at $10^{\circ} \mathrm{C}$ and as short as one day at $30-40^{\circ} \mathrm{C}$, duration of the oviposition period was as long as 11 days at $15^{\circ} \mathrm{C}$ and as short as one day at 35 and $40{ }^{\circ} \mathrm{C}$, and duration of the postoviposition period was as long as 23 days at $10^{\circ} \mathrm{C}$ and as short as two days from 25 to $40^{\circ} \mathrm{C}$. The proportion of time that oviposition occurred in the adult life span of a female varied with temperature, but not salt solution (Table 8), and the interaction was significant. Despite the significant temperature effect and interaction, the only obvious pattern in the data was that a greater proportion of the adult life span, ranging from 0.38 to 0.51 , was spent laying eggs at $25-30{ }^{\circ} \mathrm{C}$. $24-47 \%$ of the life span was spent laying eggs at $20^{\circ} \mathrm{C}$, and less than $3-35 \%$ of the life span was spent laying eggs at $10,15,35$, and $40^{\circ} \mathrm{C}$.

\subsection{Fecundity}

Females laid the most eggs, nearly 100 , at 20 and $25^{\circ} \mathrm{C}$ over $\mathrm{NaCl}$ (Table 9). Few eggs were laid at 10,35 , or $40^{\circ} \mathrm{C}$. Although fecundity differed with salt solution, interaction was significant and there was no obvious pattern to the effects of salt solution on fecundity, so we fit an equation to the data that included only temperature as an independent variable (Table 3 ). High proportions of eggs hatched at $20-30{ }^{\circ} \mathrm{C}$, while few eggs hatched at $35^{\circ} \mathrm{C}$ and no eggs hatched at $40{ }^{\circ} \mathrm{C}$ (Table 10). Few eggs were laid at $10^{\circ} \mathrm{C}$, but most 
Table 1

Mean longevity (days \pm SD) of $S$. cerealella males at constant temperatures over four humidity-controlling salt solutions.

\begin{tabular}{|c|c|c|c|c|c|c|c|}
\hline \multirow[t]{2}{*}{ Salt solution (\% r.h. range) } & \multicolumn{7}{|c|}{ Temperature $\left({ }^{\circ} \mathrm{C}\right)$} \\
\hline & 10 & 15 & 20 & 25 & 30 & 35 & 40 \\
\hline $\mathrm{K}_{2} \mathrm{CO}_{3}(40-47)$ & $18.4 \pm 6.2$ & $16.1 \pm 4.4$ & $10.2 \pm 2.9$ & $7.7 \pm 1.9$ & $6.3 \pm 1.3$ & $4.3 \pm 0.9$ & $3.6 \pm 0.5$ \\
\hline $\mathrm{NaBr}(53-63)$ & $25.8 \pm 8.8$ & $18.6 \pm 5.3$ & $12.9 \pm 4.0$ & $8.4 \pm 2.1$ & $6.0 \pm 1.7$ & $3.8 \pm 1.4$ & $4.2 \pm 0.7$ \\
\hline $\mathrm{NaCl}(75-77)$ & $31.4 \pm 11.7$ & $23.2 \pm 8.6$ & $14.7 \pm 2.9$ & $10.4 \pm 3.3$ & $7.2 \pm 1.5$ & $5.5 \pm 1.1$ & $4.8 \pm 1.2$ \\
\hline $\mathrm{KCl}(82-88)$ & $29.7 \pm 15.7$ & $23.1 \pm 8.8$ & $16.5 \pm 5.1$ & $10.6 \pm 3.6$ & $7.3 \pm 2.3$ & $6.1 \pm 1.1$ & $5.3 \pm 1.7$ \\
\hline
\end{tabular}

ANOVA results - Temperature: $F=189.9 ; \mathrm{df}=6,336 ; P<0.001$. Salt solution: $F=22.8 ; \mathrm{df}=3,336 ; P<0.001$. Interaction: $F=2.7 ; \mathrm{df}=18,336 ; P<0.001$.

Table 2

Mean longevity (days \pm SD) of S. cerealella females at constant temperatures over four humidity-controlling salt solutions.

\begin{tabular}{|c|c|c|c|c|c|c|c|}
\hline \multirow[t]{2}{*}{ Salt solution (\% r.h. range) } & \multicolumn{7}{|c|}{ Temperature $\left({ }^{\circ} \mathrm{C}\right)$} \\
\hline & 10 & 15 & 20 & 25 & 30 & 35 & 40 \\
\hline $\mathrm{K}_{2} \mathrm{CO}_{3}(40-47)$ & $22.2 \pm 8.0$ & $21.4 \pm 6.3$ & $13.2 \pm 3.8$ & $7.7 \pm 1.7$ & $6.3 \pm 0.9$ & $4.6 \pm 1.3$ & $4.8 \pm 0.9$ \\
\hline $\mathrm{NaBr}(53-63)$ & $26.2 \pm 12.1$ & $25.0 \pm 10.3$ & $12.3 \pm 3.5$ & $9.6 \pm 2.8$ & $6.8 \pm 1.6$ & $5.1 \pm 1.4$ & $4.9 \pm 1.1$ \\
\hline $\mathrm{NaCl}(75-77)$ & $27.2 \pm 9.2$ & $23.7 \pm 8.6$ & $16.2 \pm 4.9$ & $11.4 \pm 3.1$ & $7.9 \pm 2.4$ & $6.8 \pm 1.2$ & $5.8 \pm 1.2$ \\
\hline $\mathrm{KCl}(82-88)$ & $27.1 \pm 12.4$ & $28.8 \pm 12.3$ & $15.7 \pm 4.7$ & $11.1 \pm 3.5$ & $8.1 \pm 2.0$ & $7.3 \pm 2.2$ & $6.7 \pm 1.4$ \\
\hline
\end{tabular}

ANOVA results - Temperature: $F=213.3 ; \mathrm{df}=6,336 ; P<0.001$. Salt solution: $F=11.8 ; \mathrm{df}=3,336 ; P<0.001$. Interaction: $F=1.0 ; \mathrm{df}=18,336 ; P=0.483$.

hatched. We fit an equation to the data that included only temperature as an independent variable (Table 3). Over all treatments, only $4 \%$ of eggs laid were infertile. The proportions of infertile eggs laid were highest at environmental extremes - higher temperatures combined with low relative humidity (Table 11).

\section{Discussion}

Adults were able to mate and reproduce at the lowest temperature tested $\left(10^{\circ} \mathrm{C}\right)$, although duration of the preoviposition period was about three to five times longer than at $20{ }^{\circ} \mathrm{C}$ and few eggs were laid. However, at $15{ }^{\circ} \mathrm{C}$, duration of the preoviposition period was only about twice as long than at $20^{\circ} \mathrm{C}$ and 15 to 40 eggs were laid per female, while 32 to 98 eggs were laid per female at $20^{\circ} \mathrm{C}$. Weaver and Throne (1994) showed how important it is to include low temperature development of immature Angoumois grain moths in simulation models to be able to accurately predict population growth in stored corn where temperatures are below $20^{\circ}$ for about half of the storage period even in warmer climates like the southeastern U.S., and the current results indicate that even those simulated estimates for population growth were low because Angoumois grain moths are able to mate and reproduce below $20{ }^{\circ} \mathrm{C}$. In fact, a higher proportion of females laid eggs and more eggs were laid at $15^{\circ} \mathrm{C}$ than at 35 or $40{ }^{\circ} \mathrm{C}$.

Hansen et al. (2004) reported on longevity of females of a West African strain of S. cerealella reared at $20-35^{\circ} \mathrm{C}$ and 44 and $80 \%$ r.h., and longevity was longer in the current study than in the published study at both relative humidities [5-13 $\mathrm{d}$ in the current study and 5-9 d in Hansen et al., 2004 at 44\% r.h., and 7-16 d in the current study and $9-11 \mathrm{~d}$ in the Hansen et al., 2004 at $88 \%$ r.h.]. Shazali and Smith (1985) reported on longevity of a laboratory culture of S. cerealella developing on stored sorghum at $25-35{ }^{\circ} \mathrm{C}$ and

Table 3

Parameters $( \pm$ SE) for equations describing effects of temperature $(X)$ and moisture content $(Y)$ on biological processes $(Z)$ of $S$. cerealella.

\begin{tabular}{|c|c|c|c|c|c|}
\hline Process & $a$ & $b$ & $c$ & $d$ & $r^{2}$ \\
\hline Male longevity (days) ${ }^{\mathrm{a}}$ & $0.00770 \pm 0.0027$ & $0.0000208 \pm 0.0000011$ & $4.82 \pm 0.62$ & & 0.98 \\
\hline Female longevity (days) ${ }^{\mathrm{b}}$ & $23.226 \pm 1.239$ & $-416.23 \pm 24.02$ & $486.10 \pm 27.57$ & $-57.217 \pm 7.639$ & 0.99 \\
\hline Preoviposition period (days) ${ }^{c}$ & $64.555 \pm 6.384$ & $1.9491 \pm 0.2901$ & $-22.207 \pm 2.773$ & & 0.90 \\
\hline Oviposition period (days) ${ }^{\mathrm{d}}$ & $6.52 \pm 0.71$ & $-0.00344 \pm 0.00081$ & & & 0.41 \\
\hline Number of eggs laid & $-13.88 \pm 8.48$ & $1.846 \pm 0.704$ & $-0.03743 \pm 0.0143$ & & 0.79 \\
\hline Proportion of eggs hatched ${ }^{\mathrm{f}}$ & $-1.42 \pm 0.53$ & $0.202 \pm 0.046$ & $-0.00420 \pm 0.00096$ & & 0.94 \\
\hline
\end{tabular}

a Equation is of the form $1 / Z=a+b X^{2.5}+c / Y^{2}$

b Equation is of the form $\ln (Z)=a+b / X^{0.5}+c \ln (X) / X+d / Y^{2}$.

c Equation is of the form $Z=a+b X+c X^{0.5}$. Lack-of-fit: $F=0.9 ; \mathrm{df}=4,21 ; P=0.482$.

d Equation is of the form $Z=a+b X^{2}$. Lack-of-fit: $F=0.4 ; \mathrm{df}=5,21 ; P=0.815$.

e Equation is of the form $Z^{0.5}=a+b X+c X^{2}$. Lack-of-fit: $F=2.4 ; \mathrm{df}=4,21 ; P=0.080$

${ }^{\mathrm{f}}$ Equation is of the form $Z^{0.5}=a+b X+c X^{2}$. Lack-of-fit: $F=11.6 ; \mathrm{df}=3,18 ; P<0.001 .10^{\circ} \mathrm{C}$ data were excluded from the analysis because only a few eggs were laid. This equation should be bounded to not exceed 1.0 proportion eggs hatched because it slightly exceeds 1.0 at $25^{\circ} \mathrm{C}$.

Table 4

Mean proportion $( \pm \mathrm{SD})$ of $S$. cerealella females that laid eggs during their lifetime at constant temperatures over four humidity-controlling salt solutions.

\begin{tabular}{|c|c|c|c|c|c|c|c|}
\hline \multirow[t]{2}{*}{ Salt solution (\% r.h. range) } & \multicolumn{7}{|c|}{ Temperature $\left({ }^{\circ} \mathrm{C}\right)$} \\
\hline & 10 & 15 & 20 & 25 & 30 & 35 & 40 \\
\hline $\mathrm{K}_{2} \mathrm{CO}_{3}(40-47)$ & $0.17 \pm 0.41$ & $0.94 \pm 0.14$ & $100 \pm 0$ & $100 \pm 0$ & $100 \pm 0$ & $0.28 \pm 0.25$ & $0.28 \pm 0.25$ \\
\hline $\mathrm{NaBr}(53-63)$ & $0.22 \pm 0.17$ & $0.67 \pm 0.37$ & $100 \pm 0$ & $100 \pm 0$ & $100 \pm 0$ & $0.22 \pm 0.17$ & $0.17 \pm 0.18$ \\
\hline $\mathrm{NaCl}(75-77)$ & $0.17 \pm 0.28$ & $0.56 \pm 0.40$ & $100 \pm 0$ & $100 \pm 0$ & $100 \pm 0$ & $0.61 \pm 0.25$ & $0.28 \pm 0.33$ \\
\hline $\mathrm{KCl}(82-88)$ & $0.28 \pm 0.39$ & $0.50 \pm 0.28$ & $100 \pm 0$ & $100 \pm 0$ & $100 \pm 0$ & $0.39 \pm 0.25$ & $0.39 \pm 0.33$ \\
\hline
\end{tabular}


Table 5

Mean duration of the preoviposition period (days \pm SD) of $S$. cerealella females at constant temperatures over four humidity-controlling salt solutions.

\begin{tabular}{|c|c|c|c|c|c|c|c|}
\hline \multirow[t]{2}{*}{ Salt solution (\% r.h. range) } & \multicolumn{7}{|c|}{ Temperature $\left({ }^{\circ} \mathrm{C}\right)$} \\
\hline & 10 & 15 & 20 & 25 & 30 & 35 & 40 \\
\hline $\mathrm{K}_{2} \mathrm{CO}_{3}(40-47)$ & $9.3 \pm 5.6$ & $7.5 \pm 4.9$ & $4.0 \pm 3.1$ & $1.7 \pm 1.5$ & $1.4 \pm 1.1$ & $2.0 \pm 1.6$ & $1.8 \pm 0.8$ \\
\hline $\mathrm{NaBr}(53-63)$ & $16.5 \pm 9.3$ & $10.9 \pm 7.5$ & $4.3 \pm 2.5$ & $1.6 \pm 1.3$ & $1.1 \pm 0.8$ & $1.0 \pm 1.2$ & $1.7 \pm 1.5$ \\
\hline $\mathrm{NaCl}(75-77)$ & $15.7 \pm 5.1$ & $6.8 \pm 5.0$ & $3.1 \pm 2.3$ & $1.9 \pm 1.7$ & $1.3 \pm 1.3$ & $2.8 \pm 2.2$ & $0.8 \pm 0.4$ \\
\hline $\mathrm{KCl}(82-88)$ & $12.6 \pm 3.4$ & $9.3 \pm 6.0$ & $3.9 \pm 4.6$ & $1.7 \pm 1.0$ & $1.7 \pm 1.1$ & $2.9 \pm 1.3$ & $2.6 \pm 1.9$ \\
\hline
\end{tabular}

ANOVA results - Temperature: $F=45.0 ; \mathrm{df}=6,188 ; P<0.001$. Salt solution: $F=2.4 ; \mathrm{df}=3,188 ; P=0.067$. Interaction: $F=1.7 ; \mathrm{df}=18,188 ; P=0.048$.

Table 6

Mean duration of the oviposition period (days \pm SD) of $S$. cerealella females at constant temperatures over four humidity-controlling salt solutions.

\begin{tabular}{|c|c|c|c|c|c|c|c|}
\hline \multirow[t]{2}{*}{ Salt solution (\% r.h. range) } & \multicolumn{7}{|c|}{ Temperature $\left({ }^{\circ} \mathrm{C}\right)$} \\
\hline & 10 & 15 & 20 & 25 & 30 & 35 & 40 \\
\hline $\mathrm{K}_{2} \mathrm{CO}_{3}(40-47)$ & $10.3 \pm 8.6$ & $3.6 \pm 3.0$ & $4.6 \pm 3.0$ & $3.6 \pm 0.8$ & $2.4 \pm 1.1$ & $1.0 \pm 0.0$ & $1.8 \pm 0.8$ \\
\hline $\mathrm{NaBr}(53-63)$ & $7.8 \pm 5.4$ & $4.9 \pm 3.2$ & $2.8 \pm 2.3$ & $4.9 \pm 2.1$ & $3.4 \pm 1.1$ & $1.3 \pm 0.5$ & $1.7 \pm 1.2$ \\
\hline $\mathrm{NaCl}(75-77)$ & $1.0 \pm 0.0$ & $7.0 \pm 7.9$ & $7.8 \pm 3.9$ & $5.2 \pm 1.6$ & $3.4 \pm 1.1$ & $2.0 \pm 1.3$ & $2.0 \pm 0.0$ \\
\hline $\mathrm{KCl}(82-88)$ & $2.4 \pm 3.1$ & $11.4 \pm 11.9$ & $5.7 \pm 3.3$ & $4.7 \pm 2.1$ & $3.6 \pm 1.5$ & $1.4 \pm 0.8$ & $1.0 \pm 0.0$ \\
\hline
\end{tabular}

ANOVA results - Temperature: $F=9.4 ; \mathrm{df}=6,188 ; P<0.001$. Salt solution: $F=0.4 ; \mathrm{df}=3,188 ; P=0.741$. Interaction: $F=2.8 ; \mathrm{df}=18,188 ; P<0.001$.

averaged for both sexes from 60 to $80 \%$ r.h., and longevity was similar in the two studies [3-10 d in the current study and 4-9 d in Shazali and Smith, 1985]. Boldt (1974) reported longevity of S. cerealella females developing on stored wheat at $20-40{ }^{\circ} \mathrm{C}$ and $80 \%$ r.h., and longevity was similar in the two studies [7-16 d in the current study and 6-15 d in Boldt, 1974]. Grewal and Atwal (1969) reported on longevity of $S$. cerealella females reared on stored corn at $20-40{ }^{\circ} \mathrm{C}$ and 40 and $80 \%$ r.h., and longevity generally was longer in the current study than in the published study at 20 and $25^{\circ} \mathrm{C}$ [8$16 \mathrm{~d}$ in the current study and 7-11 d in Grewal and Atwal, 1969] but similar at 30 and $35^{\circ} \mathrm{C}(5-8 \mathrm{~d}$ in the current study and $3-8 \mathrm{~d}$ in Grewal and Atwal, 1969]. In general, female longevity was similar at higher temperatures in all studies despite differences among the studies in strain of insect used and crop on which the insects were reared, but differences in longevity among studies became noticeable at lower temperatures where females lived more than a few days.

Previous studies reported limited observations on duration of the preoviposition period which usually has been reported as about one day (Crombie, 1943; Hansen et al., 2004). We found that the preoviposition period was longer than one day and lasted from 9 to
17 days at $10^{\circ} \mathrm{C}, 7-11 \mathrm{~d}$ at $15^{\circ} \mathrm{C}, 4 \mathrm{~d}$ at $20^{\circ} \mathrm{C}, 1-2$ d at 25 and $30^{\circ} \mathrm{C}$, and $1-3 \mathrm{~d}$ at 35 and $40^{\circ} \mathrm{C}$. In the current study, all eggs were laid in $1-2 \mathrm{~d}$ at 35 and $40^{\circ} \mathrm{C}, 2-5 \mathrm{~d}$ at $25-30^{\circ} \mathrm{C}, 3-11 \mathrm{~d}$ at 15 and $20^{\circ} \mathrm{C}$, and $1-10 \mathrm{~d}$ at $10^{\circ} \mathrm{C}$, and these values are similar to previously published values at $25-35^{\circ} \mathrm{C}$ (Shazali and Smith, 1985) and 20$40{ }^{\circ} \mathrm{C}$ (Boldt, 1974). Sitotroga cerealella do not feed as adults, so all adult life processes would be expected to be rapidly completed.

Lifetime fecundity was reported as about 80-90 and 100-125 eggs at $44 \%$ and $60-80 \%$ r.h. at $20-30{ }^{\circ} \mathrm{C}$ in previous studies (Shazali and Smith, 1985; Hansen et al., 2004), with numbers reduced to about $25-60$ eggs at $35^{\circ} \mathrm{C}$. Results were similar on a number of rice varieties stored at $27{ }^{\circ} \mathrm{C}$ and $75 \%$ r.h. (Yadav et al., 2003), but fecundity tended to be higher (137-165), with the exception of only 85 eggs laid on one genotype, on different genotypes of corn stored at $27{ }^{\circ} \mathrm{C}$ and $50 \%$ r.h. (Consoli and AmaralFilho, 1995). Shazali and Smith (1985) also reported higher fecundity on sorghum stored at $20-30^{\circ} \mathrm{C}$, with $119-136,131-165$, and 144-178 eggs laid at $40 \%, 60$, and $80 \%$ r.h., respectively, and 80-121 eggs laid at $35{ }^{\circ} \mathrm{C}$ at these same relative humidities. Fecundity in our study tended to be lower at all temperatures, with six or fewer eggs laid at 35 and $40^{\circ} \mathrm{C}, 30-100$ eggs laid at $20-30{ }^{\circ} \mathrm{C}$ depending

Table 7

Mean duration of the postoviposition period (days \pm SD) of $S$. cerealella females at constant temperatures over four humidity-controlling salt solutions.

\begin{tabular}{|c|c|c|c|c|c|c|c|}
\hline \multirow[t]{2}{*}{ Salt solution (\% r.h. range) } & \multicolumn{7}{|c|}{ Temperature $\left({ }^{\circ} \mathrm{C}\right)$} \\
\hline & 10 & 15 & 20 & 25 & 30 & 35 & 40 \\
\hline $\mathrm{K}_{2} \mathrm{CO}_{3}(40-47)$ & $9.0 \pm 3.0$ & $10.2 \pm 5.4$ & $4.6 \pm 1.6$ & $2.3 \pm 0.7$ & $2.5 \pm 0.6$ & $2.4 \pm 0.9$ & $1.8 \pm 0.8$ \\
\hline $\mathrm{NaBr}(53-63)$ & $16.5 \pm 1.0$ & $7.9 \pm 6.8$ & $5.2 \pm 2.2$ & $3.0 \pm 1.1$ & $2.3 \pm 0.8$ & $3.0 \pm 1.6$ & $2.0 \pm 0.0$ \\
\hline $\mathrm{NaCl}(75-77)$ & $16.7 \pm 2.3$ & $10.1 \pm 9.0$ & $5.0 \pm 2.5$ & $4.3 \pm 1.8$ & $3.2 \pm 1.7$ & $2.2 \pm 1.2$ & $3.4 \pm 0.5$ \\
\hline $\mathrm{KCl}(82-88)$ & $22.8 \pm 14.0$ & $10.7 \pm 7.8$ & $5.9 \pm 2.2$ & $4.9 \pm 3.1$ & $2.8 \pm 1.2$ & $4.1 \pm 1.2$ & $3.3 \pm 2.0$ \\
\hline
\end{tabular}

ANOVA results - Temperature: $F=48.7 ; \mathrm{df}=6,188 ; P<0.001$. Salt solution: $F=5.1 ; \mathrm{df}=3,188 ; P=0.002$. Interaction: $F=1.7 ; \mathrm{df}=18,188 ; P=0.050$.

Table 8

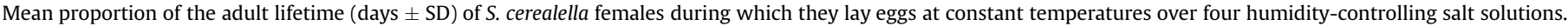

\begin{tabular}{|c|c|c|c|c|c|c|c|}
\hline \multirow[t]{2}{*}{ Salt solution (\% r.h. range) } & \multicolumn{7}{|c|}{ Temperature $\left({ }^{\circ} \mathrm{C}\right)$} \\
\hline & 10 & 15 & 20 & 25 & 30 & 35 & 40 \\
\hline $\mathrm{K}_{2} \mathrm{CO}_{3}(40-47)$ & $0.35 \pm 0.27$ & $0.17 \pm 0.13$ & $0.34 \pm 0.18$ & $0.48 \pm 0.11$ & $0.38 \pm 0.16$ & $0.21 \pm 0.08$ & $0.35 \pm 0.19$ \\
\hline $\mathrm{NaBr}(53-63)$ & $0.20 \pm 0.15$ & $0.21 \pm 0.12$ & $0.24 \pm 0.18$ & $0.51 \pm 0.17$ & $0.50 \pm 0.12$ & $0.30 \pm 0.25$ & $0.32 \pm 0.24$ \\
\hline $\mathrm{NaCl}(75-77)$ & $0.03 \pm 0.01$ & $0.28 \pm 0.27$ & $0.47 \pm 0.20$ & $0.48 \pm 0.14$ & $0.44 \pm 0.14$ & $0.30 \pm 0.21$ & $0.33 \pm 0.05$ \\
\hline $\mathrm{KCl}(82-88)$ & $0.07 \pm 0.09$ & $0.33 \pm 0.25$ & $0.38 \pm 0.21$ & $0.44 \pm 0.18$ & $0.45 \pm 0.15$ & $0.17 \pm 0.08$ & $0.15 \pm 0.01$ \\
\hline
\end{tabular}

ANOVA results - Temperature: $F=15.0 ; \mathrm{df}=6,188 ; P<0.001$. Salt solution: $F=1.4 ; \mathrm{df}=3,188 ; P=0.242$. Interaction: $F=2.4 ; \mathrm{df}=18,188 ; P=0.002$. 
Table 9

Mean number of eggs laid $( \pm \mathrm{SD})$ by $S$. cerealella females at constant temperatures over four humidity-controlling salt solutions.

\begin{tabular}{|c|c|c|c|c|c|c|c|}
\hline \multirow[t]{2}{*}{ Salt solution (\% r.h. range) } & \multicolumn{7}{|c|}{ Temperature $\left({ }^{\circ} \mathrm{C}\right)$} \\
\hline & 10 & 15 & 20 & 25 & 30 & 35 & 40 \\
\hline $\mathrm{K}_{2} \mathrm{CO}_{3}(40-47)$ & $0.3 \pm 0.8$ & $39.6 \pm 50.8$ & $41.8 \pm 40.5$ & $65.7 \pm 48.8$ & $48.9 \pm 57.0$ & $0.3 \pm 0.6$ & $1.5 \pm 4.1$ \\
\hline $\mathrm{NaBr}(53-63)$ & $0.7 \pm 1.3$ & $19.6 \pm 28.9$ & $32.6 \pm 41.7$ & $70.8 \pm 45.3$ & $77.6 \pm 64.3$ & $3.6 \pm 10.8$ & $2.4 \pm 7.6$ \\
\hline $\mathrm{NaCl}(75-77)$ & $0.2 \pm 0.5$ & $15.7 \pm 27.9$ & $97.7 \pm 62.4$ & $97.4 \pm 44.5$ & $65.3 \pm 32.6$ & $3.4 \pm 6.4$ & $5.6 \pm 11.0$ \\
\hline $\mathrm{KCl}(82-88)$ & $0.3 \pm 0.6$ & $16.8 \pm 25.3$ & $71.4 \pm 58.5$ & $64.7 \pm 35.6$ & $52.0 \pm 48.0$ & $6.2 \pm 13.4$ & $1.3 \pm 3.3$ \\
\hline
\end{tabular}

ANOVA results - Temperature: $F=62.2 ; \mathrm{df}=6,336 ; P<0.001$. Salt solution: $F=3.4 ; \mathrm{df}=3,336 ; P=0.017$. Interaction: $F=3.0 ; \mathrm{df}=18,336 ; P<0.001$.

Table 10

Mean proportion of eggs laid $( \pm \mathrm{SD})$ by $S$. cerealella females that hatched at constant temperatures over four humidity-controlling salt solutions.

\begin{tabular}{|c|c|c|c|c|c|c|c|}
\hline \multirow[t]{2}{*}{ Salt solution (\% r.h. range) } & \multicolumn{7}{|c|}{ Temperature $\left({ }^{\circ} \mathrm{C}\right)$} \\
\hline & 10 & 15 & 20 & 25 & 30 & 35 & 40 \\
\hline $\mathrm{K}_{2} \mathrm{CO}_{3}(40-47)$ & $1.00 \pm 0.00$ & $0.51 \pm 0.45$ & $0.91 \pm 0.17$ & $0.87 \pm 0.16$ & $0.79 \pm 0.33$ & $0.20 \pm 0.45$ & $0.00 \pm 0.00$ \\
\hline $\mathrm{NaBr}(53-63)$ & $0.58 \pm 0.32$ & $0.40 \pm 0.43$ & $0.87 \pm 0.26$ & $0.93 \pm 0.08$ & $0.91 \pm 0.10$ & $0.13 \pm 0.26$ & $0.00 \pm 0.00$ \\
\hline $\mathrm{NaCl}(75-77)$ & $1.00 \pm 0.00$ & $0.41 \pm 0.43$ & $0.84 \pm 0.32$ & $0.98 \pm 0.02$ & $0.87 \pm 0.13$ & $0.03 \pm 0.10$ & $0.00 \pm 0.00$ \\
\hline $\mathrm{KCl}(82-88)$ & $0.90 \pm 0.22$ & $0.45 \pm 0.36$ & $0.98 \pm 0.05$ & $0.97 \pm 0.03$ & $0.68 \pm 0.30$ & $0.03 \pm 0.07$ & $0.00 \pm 0.00$ \\
\hline
\end{tabular}

ANOVA results - Temperature: $F=80.5 ; \mathrm{df}=6,188 ; P<0.001$. Salt solution: $F=0.3 ; \mathrm{df}=3,188 ; P=0.851$. Interaction: $F=1.9 ; \mathrm{df}=18,188 ; P=0.023$.

Table 11

Mean proportion of eggs laid $( \pm \mathrm{SD})$ by $S$. cerealella females that were infertile at constant temperatures over four humidity-controlling salt solutions.

\begin{tabular}{|c|c|c|c|c|c|c|c|}
\hline \multirow[t]{2}{*}{ Salt solution (\% r.h. range) } & \multicolumn{7}{|c|}{ Temperature $\left({ }^{\circ} \mathrm{C}\right)$} \\
\hline & 10 & 15 & 20 & 25 & 30 & 35 & 40 \\
\hline $\mathrm{K}_{2} \mathrm{CO}_{3}(40-47)$ & $0.00 \pm 0.00$ & $0.02 \pm 0.08$ & $0.00 \pm 0.00$ & $0.05 \pm 0.12$ & $0.16 \pm 0.33$ & $0.20 \pm 0.45$ & $0.40 \pm 0.55$ \\
\hline $\mathrm{NaBr}(53-63)$ & $0.08 \pm 0.17$ & $0.13 \pm 0.30$ & $0.00 \pm 0.01$ & $0.01 \pm 0.02$ & $0.03 \pm 0.06$ & $0.12 \pm 0.23$ & $0.00 \pm 0.00$ \\
\hline $\mathrm{NaCl}(75-77)$ & $0.00 \pm 0.00$ & $0.12 \pm 0.31$ & $0.00 \pm 0.01$ & $0.00 \pm 0.00$ & $0.01 \pm 0.01$ & $0.09 \pm 0.30$ & $0.00 \pm 0.00$ \\
\hline $\mathrm{KCl}(82-88)$ & $0.00 \pm 0.00$ & $0.01 \pm 0.04$ & $0.01 \pm 0.05$ & $0.01 \pm 0.01$ & $0.01 \pm 0.02$ & $0.01 \pm 0.03$ & $0.14 \pm 0.38$ \\
\hline
\end{tabular}

ANOVA results - Temperature: $F=4.8 ; \mathrm{df}=6,188 ; P<0.001$. Salt solution: $F=5.6 ; \mathrm{df}=3,188 ; P=0.001$. Interaction: $F=2.6 ; \mathrm{df}=18,188 ; P=0.001$.

upon relative humidity and temperature, $15-40$ eggs at $15^{\circ} \mathrm{C}$, and less than one egg at $10^{\circ} \mathrm{C}$.

Percentage egg hatch tends to be high (70-95\%) at $20-30{ }^{\circ} \mathrm{C}$ (Shazali and Smith, 1985; Consoli and Amaral-Filho, 1995; Yadav et al., 2003), but drops off outside this range to $52-60 \%$ at $35{ }^{\circ} \mathrm{C}$ (Shazali and Smith, 1985). Grewal and Atwal (1969) also reported lower egg survivorship of $47-65 \%$ at $20{ }^{\circ} \mathrm{C}, 60 \%$ at $25{ }^{\circ} \mathrm{C}$ and $40 \%$ r.h., and $28-55 \%$ at $35{ }^{\circ} \mathrm{C}$. Our results were similar, except with lower survivorship at $35{ }^{\circ} \mathrm{C}$ of $3-20 \%$. In addition, we had no eggs hatch at $40{ }^{\circ} \mathrm{C}, 40-50 \%$ hatch at $15^{\circ} \mathrm{C}$, and $60-100 \%$ hatch at $10{ }^{\circ} \mathrm{C}$ where only a few eggs were laid.

Our results emphasize the importance of including data on population growth of stored-grain insect pests at low temperatures in computer models for simulating insect population growth in grain stored in the U.S. Sitotroga cerealella mated and reproduced at $10{ }^{\circ} \mathrm{C}$, and temperatures below $20^{\circ} \mathrm{C}$ are common for half the year or more in grain stored in the U.S. Thus, inclusion of data for insects developing at low temperatures should improve the accuracy of simulation models developed to aid in decision making for management of stored-grain insect pests in the U.S.

\section{Acknowledgments}

We thank Rizana Mahroof for reviewing an earlier version of the manuscript. Mention of trade names or commercial products in this publication is solely for the purpose of providing specific information and does not imply recommendation or endorsement by the U.S. Department of Agriculture. USDA is an equal opportunity provider and employer. Part of the writing of this manuscript was supported by the Montana Ag Experiment Station.

\section{References}

Arbogast, R.T., Throne, J.E., 1997. Insect infestation of farm-stored maize in South Carolina: towards characterization of a habitat. J. Stored Prod. Res. 33, 187198.

Boldt, P.E., 1974. Effects of temperature and humidity on development and oviposition of Sitotroga cerealella (Lepidoptera: Gelechiidae). J. Kans. Entomol. Soc. 47, $30-36$.

Consoli, F.L., Amaral-Filho, B.F., 1995. Biology of Sitotroga cerealella (Oliv.) (Lepidoptera: Gelechiidae) reared on five corn (maize) genotypes. J. Stored Prod. Res. 31, 139-143.

Crombie, A.C., 1943. The development of the Angoumois grain moth (Sitotroge cerealella Oliv.). Nature 152, 246.

Draper, N.R., Smith, H., 1981. Applied Regression Analysis, second ed. John Wiley \& Sons, New York.

Greenspan, L., 1977. Humidity fixed points of binary saturated aqueous solutions J. Res. Natl. Bur. Stand. A81, 89-96.

Grewal, S.S., Atwal, A.S., 1969. The influence of temperature and humidity on the development of Sitotroga cerealella Oliver (Gelechiidae, Lepidoptera). J. Res. Punjab Agric. Univ. 6, 353-358.

Hansen, L.S., Skovgard, H., Hell, K., 2004. Life table study of Sitotroga cerealella (Lepidoptera: Gelichiidae), a strain from West Africa. J. Econ. Entomol. 97, 1484-1490.

Perez-Mendoza, J., Weaver, D.K., Throne, J.E., 2004. Development and survivorship of immature Angoumois grain moth (Lepidoptera: Gelechiidae) on stored corn. Environ. Entomol. 33, 807-814.

Peters, L.L., 1971. Angoumois grain moth egg collection. J. Econ. Entomol. 64, 13081309.

SAS Institute, 2008. SAS 9.2 for Windows. SAS Institute Inc., Cary.

Shahjahan, M., 1975. Some aspects of the ecology and control of Sitotroga cerealella Oliv (Lepidoptera: Gelechidae) in Bangladesh. J. Stored Prod. Res. 11, 239-242.

Shazali, M.E.H., Smith, R.H., 1985. Life history studies of internally feeding pests of stored sorghum: Sitotroga cerealella (Ol.) and Sitophilus oryzae (L.). J. Stored Prod. Res. 21, 171-178.

SYSTAT Software Inc., 2002a. TableCurve 2D ${ }^{\circledR}$, Version 5.1. SYSTAT Software Inc., San Jose.

SYSTAT Software Inc., 2002b. TableCurve 3D ${ }^{\circledR}$, Version 4.0. SYSTAT Software Inc., San Jose.

Throne, J.E., 1994. Life history of immature maize weevils (Coleoptera: Curculionidae) on corn stored at constant temperatures and relative humidities in the laboratory. Environ. Entomol. 23, 1459-1471. 
Weaver, D.K., Throne, J.E., 1994. Life history data for Sitotroga cerealella (Olivier) (Lepidoptera: Gelechiidae) in farm-stored corn and the importance of suboptimal environmental conditions in insect population modelling for bulk commodities. In: Highley, E., Wright, E.J., Banks, H.J., Champ, B.R. (Eds.), Proceedings of the Sixth International Working Conference on Stored-product Protection, Canberra, Australia, 17-23 April 1994. CAB International, Wallingford, UK, pp. 599-603.
Wicklow, D.T., Weaver, D.K., Throne, J.E., 1998. Fungal colonists of maize grain conditioned at constant temperatures and humidities. J. Stored Prod. Res. 34, 355-361.

Yadav, U.S., Prasad, S.S., Upadhyay, K.D., Ram, M., 2003. Growth and development of angoumois grain moth, Sitotroga cerealella Olivier on different rice varieties. Proc. Natl. Acad. Sci. India 73B, 283-290. 